LOCAL WISDOM, 13 (1): $13-22,2021$
Local Wisdom Scientific Online Journal
ISSN: 2086-3764

\title{
Tourism Destination Based on Local Values in Wonosoco Village, Kudus Regency, Indonesia
}

\author{
Noor Fatmawati ${ }^{*}$, Aditya Isnaini Prasetya ${ }^{2}$ \\ ${ }^{1}$ Fakultas Tarbiyah, IAIN Kudus, Jl. Conge Ngembalrejo PO BOX 51 Kudus, 59322 \\ 2SMA Negeri 1 Gabus, Jl. Punden Tlogotirto, Kec. Gabus, Kab. Grobogan \\ Corresponding Author: noorfatmawati64@yahoo.com
}

\begin{tabular}{|c|c|}
\hline & Abstract \\
\hline $\begin{array}{l}\text { Keywords: } \\
\text { Tourist Destinations; } \\
\text { Values; Local Wisdom }\end{array}$ & $\begin{array}{l}\text { Wonosoco Village has natural and cultural phenomena based on local } \\
\text { wisdom that have the potential as a tourist destination. However, the } \\
\text { lack of understanding of the village community in developing tourism } \\
\text { potential as well as the geographical conditions of the village which } \\
\text { are prone to landslides and flash floods, it is difficult to be promoted } \\
\text { to become a tourist village, so the community does not understand the } \\
\text { essence of the values of village local wisdom. The purpose of this } \\
\text { study is to analyze tourist destinations based on local wisdom values } \\
\text { in Wonosoco Village, Kudus Regency. The qualitative research } \\
\text { method used is a phenomenological approach. The main informants } \\
\text { are the village head, with informants supporting the village } \\
\text { community, Pokdarwis members, and tourists. Retrieval of data } \\
\text { through observation and interview techniques with data analysis } \\
\text { using the Spradley Model through the stages of analysis of domains, } \\
\text { taxonomies, components, and cultural themes. The findings show that } \\
\text { there are potential tourist destinations, namely natural resources, } \\
\text { human resources, recreational facilities, and events organized by the } \\
\text { government. This tourist destination essentially has local wisdom } \\
\text { values in the form of spiritual values, social values, and cultural } \\
\text { values that can construct knowledge for the community to be realized } \\
\text { in everyday life, so it needs to be preserved to provide a transfer of } \\
\text { values to generations to respect the values of wisdom. local culture. }\end{array}$ \\
\hline $\begin{array}{l}\text { DOI: https:/ / doi.or } \\
\text { @ } 2017 \text { The Authors. I }\end{array}$ & $\begin{array}{lllll}/ 10.26905 / \text { lw.v13i1.4723 } & \text { Article } & \text { Received } & \text { Aug 8, 2020 } \\
\text { tblished by GKAK UNMER Malang } & \text { History } & \text { Accepted } & : & \text { Oct 10, 2020 } \\
& & \text { Published } & : & \text { Jan 15, 2021 }\end{array}$ \\
\hline
\end{tabular}

\section{INTRODUCTION}

Tourism is one of the mainstay sectors that can have a big impact on the progress of a region. The Ministry of Culture and Tourism (2009) has explained that the tourism sector is a very important source of foreign exchange (Susyanti \& Latianingsih, 2014: 67). Tourism is the total number of phenomena and relationships arising from interactions between tourists, business suppliers, host governments, host communities, original governments, universities, collages of societies and non-governmental organizations, in the process of attracting, transporting, organizing and managing tourists. as well as other visitors.

This tourism must be in accordance with the principles of "proper tourism" in order to provide benefits to local communities and tourists. The principles of "proper tourism" 


\section{Tourism Destination Based on Local Values in Wonosoco Village, Kudus Regency, Indonesia \\ Noor Fatmawati, Aditya Isnaini Prasetya}

according to Marpaung and Bahar (2002: 45-46) are to actively encourage the continuity of heritage in an area-culture, history, and nature; emphasizing and presenting regional identity as something unique; empowering local people to interpret their own heritage to guests (tourists); building local people's pride in their heritage and enhancing guest relations and service skills; help maintain local lifestyles and values; as well as presenting an approach towards sustainable tourism development.

Proper tourism is basically being able to bring out the uniqueness of the local cultural wisdom which is continuously maintained and developed. In connection with this, there is the term tourism destination which is intended for a place or object visited by tourists. The characteristics of these destinations are natural resource destinations; destination of human cultural resources; recreational facilities, such as amusement parks; and events (Pitana and Diarta, 2009: 126).

The characteristics of this tourist destination can be seen in a village that has been legally designated as a tourist village. Tourism village according to the Directorate General of Tourism (1999) is a rural area that can be utilized based on the ability of elements that have integrated tourism product attributes, where the village offers an overall atmosphere that has a theme by reflecting rural authenticity, both in terms of social life. , culture, economy, and daily customs which have distinctive architectural characteristics and village layouts become a series of tourism activities.

Tourism plays a role in encouraging public awareness of local natural and cultural wealth as a form of cultural preservation (Haryanto, 2013: 4). Cultural preservation in Koentjaraningrat (1984) is a system that has various components related to the subsystem of life in society (Triwardani and Rochayanti, 2014: 103).

In essence, people's life cannot be separated from the culture they produce, so that culture has a profound influence on human behaviour. Therefore, tourism can encourage interaction between individuals to realize cultural preservation. Cultural preservation is realized by exploring the potential of village tourism destinations, which geographically have a variety of natural beauty and local culture that reflects the characteristics of the village. Potential tourist destinations must of course be following the principles of proper tourism, namely by presenting identity and maintaining the values of local village wisdom (Marpaung and Bahar, 2002: 45).

Village local wisdom includes all forms of belief, understanding, and customs that guide the behaviour of rural communities in their social life, as well as the results of physical culture in the form of artefact or other historical objects (Maryani \& Yani: 116). This local wisdom describes how individuals behave and act in response to changes in the physical and cultural environment (Istiawati, 2016: 5). Village local wisdom can also be a driving force to accelerate the empowerment process of village communities (Sidik, 2015: 128).

Village local wisdom can be seen in Wonosoco Village, which is located in Undaan Regency, Kudus Regency. This village has the potential of a tourist destination that can develop the economy of the village community, so the Government of Kudus Regency was appointed as a pilot village for tourism in 2009. It was designated as a pioneering tourism village because it has local cultural characteristics and natural beauty that is still pure and beautiful types of the countryside (Wulan \& Khadiyanto , 2013). A tourist village according to Pitana (in Permanasari, 2011: 11) is a rural area with an overall atmosphere that reflects the authenticity of the village, both from the spatial structure, building architecture, as well as the socio-cultural life pattern of the community, as well as being able to provide 


\section{Tourism Destination Based on Local Values in Wonosoco Village, Kudus Regency, Indonesia Noor Fatmawati, Aditya Isnaini Prasetya}

components of basic tourist needs such as accommodation. , food and drink, souvenirs, and tourist attractions.

The uniqueness of Wonosoco Village according to the local community is that it has many tourist destinations in one village, both natural and cultural destinations. Natural destinations in the form of Teak Forest Park, Sendang Dewot, Sendang Ganding, Batu Cantik Cave, Keraton Cave, Surodipo Cave, Kendeng Mountains, Camping Ground, culinary centres, and gardens specially made for tourist stopovers. Cultural destinations are in the form of local wisdom that is still inherent in society, such as the tradition of cooperation (sambatan), cultural ceremonies, sendang rehearsals, and Wayang Klithik performances that have been preserved from generation to generation by future generations.

These natural and cultural tourism destinations have values which can directly provide understanding to the community about the importance of protecting and preserving the natural and cultural environment. Fatmawati, Setyowati, \& Utomo (2018: 89) explain that human experience from their interactions with the environment will effect on their ethics to surrounding environment. Besides, the existence of these destinations can capture social interactions between the community and tourists which can show the community the values of socializing. This reality reflects that Wonosoco Village has the characteristics of a tourist village, but the defence of local natural and cultural wisdom of this village has not received maximum attention from the village community and the government.

The Head of Wonosoco Village explained that it was designated as a tourism village pilot since 2009, but until now it has not been designated as a tourist village. This is because the village community managing tourism who are members of the Tourism Awareness Group (Pokdarwis) do not have a specific understanding in developing a tourist village, so that the tourism potential in the village is not developed as an attractive destination. Besides, the geographical conditions of the village which is located on the slopes of the Kendeng Mountains are very vulnerable to flash floods that hit the village community settlements, but the right solution has not been found in dealing with flash floods that can hit this village at any time.

These problems make promotion as a tourist village very difficult to do, so that the village community and society in general do not understand the values of local wisdom in Wonosoco Village. Even though local wisdom contained in an area can teach someone to adapt, care about cultural heritage, and form positive social attitudes (Hairumini, Setyowati, and Sanjoto, 2016: 37). This writing aims to analyze the potential of tourist destinations based on the values of local wisdom in Wonosoco Village, Kudus Regency. This research is expected to be able to provide experience for the community in understanding the social and cultural values that exist in their environment so that they can be realized in the life of society, nation and state.

\section{RESEARCH METHODOLOGY}

This study uses a qualitative research method with a phenomenological approach. The phenomenological approach according to Manen in Saevi (2017: 1792) aims to find the meaning of the local wisdom values contained in tourist destinations in Wonosoco Village. The focus of this research is the potential for tourist destinations based on local wisdom values in Wonososco Village. The main informants are the village head, with informants supporting the village community, Pokdarwis members, and tourists. 


\section{Tourism Destination Based on Local Values in Wonosoco Village, Kudus Regency, Indonesia \\ Noor Fatmawati, Aditya Isnaini Prasetya}

Data were collected using observation and interview techniques. Observations were made directly in Wonosoco Village by observing various phenomena of existing tourist destinations. Interviews were conducted in the form of unstructured interviews and open interviews with key informants and supporting informants. The data validity test was conducted by triangulating sources to compare and cross-check the degree of trustworthiness of information obtained through different time and tools (Moleong, 2010). Data analysis used the Spradley Model through the analysis stages of domains, taxonomies, components, and cultural themes. The Spradley Model analysis stages were used because this study was included in a complex qualitative study based on a phenomenological approach.

\section{RESULTS AND DISCUSSION}

Wonosoco Village is located in Undaan Subdistrict, Kudus Regency, Indonesia. Geographically, this village is located on the slopes of the Kendeng Mountains and close to a river, so it is very vulnerable to landslides and flash floods. This village has the appearance of settlements, forests, caves, mountains, rivers, rice fields, and springs. Settlements are located in the centre of the village with an elongated pattern following the road around which there are forests. The majority of the forest in this village is planted with teak trees and partly in the form of corn and cassava plants.

The forest area is located in the eastern part of the village with four caves, namely Surodipo Cave, Keraton Cave, Wewe Cave and Batu Cantik Cave. Beside, it can be seen that the Kendeng Mountains line the southern part of the village with a river flowing along the front of the village which is adjacent to the residents' rice fields. Two springs flow around residential areas, namely Sendang Dewot and Sendang Gading. Uniquely, these two springs are located in the West and East of the residential area, so that each settlement point has its water supply to meet the needs of the population.

Wonosoco village has the potential to be a tourist destination, because there are various natural tourist spots and they still preserve local culture. This can be proven by the characteristics of tourist destinations, namely natural resource destinations, human resources, recreational facilities, and events that can attract tourist visits (Pitana and Diarta, 2009: 126). For tourists who come to this village, the government provides a tourist map in front of the village gate. Tourists can visit destinations that are tourist destinations easily through the tourist map image as shown in Figure 1.

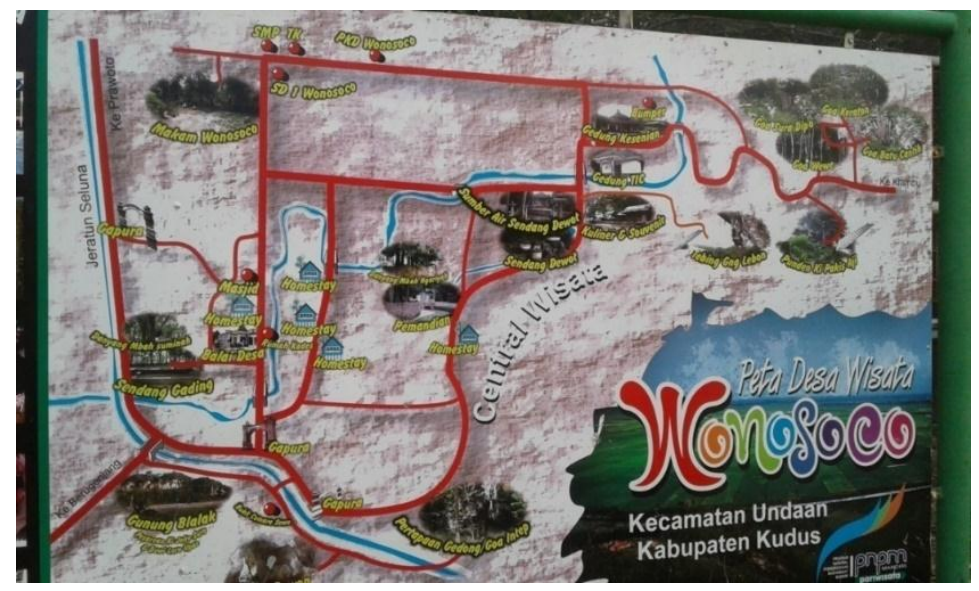

Figure 1. Tourist Map Wonosoco Village 


\section{Tourism Destination Based on Local Values in Wonosoco Village, Kudus Regency, Indonesia \\ Noor Fatmawati, Aditya Isnaini Prasetya}

(Source: Research Documentation, 2018) Table 1.

The following is an explanation of the tourist destinations in Wonosoco Village in

\begin{tabular}{|c|c|}
\hline Tourism Destinations & Research Outcomes \\
\hline $\begin{array}{l}\text { Natural resource } \\
\text { destination }\end{array}$ & $\begin{array}{l}\text { - Teak forest } \\
\text { - Batu Cantik Cave } \\
\text { - Goa Keraton } \\
\text { - Surodipo Cave } \\
\text { - Sendang Dewot } \\
\text { - Sendang Gading } \\
\text { - Kendeng Mountains } \\
\text { - Rice fields }\end{array}$ \\
\hline $\begin{array}{l}\text { Human resource } \\
\text { destinations }\end{array}$ & $\begin{array}{l}\text { - Culture } \\
\text { - Tradition } \\
\text { - Local culture }\end{array}$ \\
\hline Recreational facilities & $\begin{array}{l}\text { - Gardens } \\
\text { - Shop } \\
\text { - Sanitation } \\
\text { - Homestay } \\
\text { - Swimming pool } \\
\text { - Campground } \\
\text { - The arts building }\end{array}$ \\
\hline Event & $\begin{array}{l}\text { - Cultural Carnival } \\
\text { - Dress-up Sendang } \\
\text { - Wayang Klithik } \\
\text { performance }\end{array}$ \\
\hline
\end{tabular}

(Source: Research Data, 2018)

\section{Destination Natural Resources}

Natural resources in this village that can be used for various destinations are teak forests, caves, spring, mountains, and rice fields. This destination has been made as attractive as possible to attract tourists, thus presenting a comfortable and cool atmosphere typical of the countryside when visited. In addition, tourists who will visit one or all of the natural destinations offered, there are tours, making it easier for tourists to explore all the natural beauty in this village. The natural beauty and tourist destinations in the form of Sendang Dewot in Wonosoco Tourism Village can be seen in Figure 2. 


\section{Tourism Destination Based on Local Values in Wonosoco Village, Kudus Regency, Indonesia Noor Fatmawati, Aditya Isnaini Prasetya}

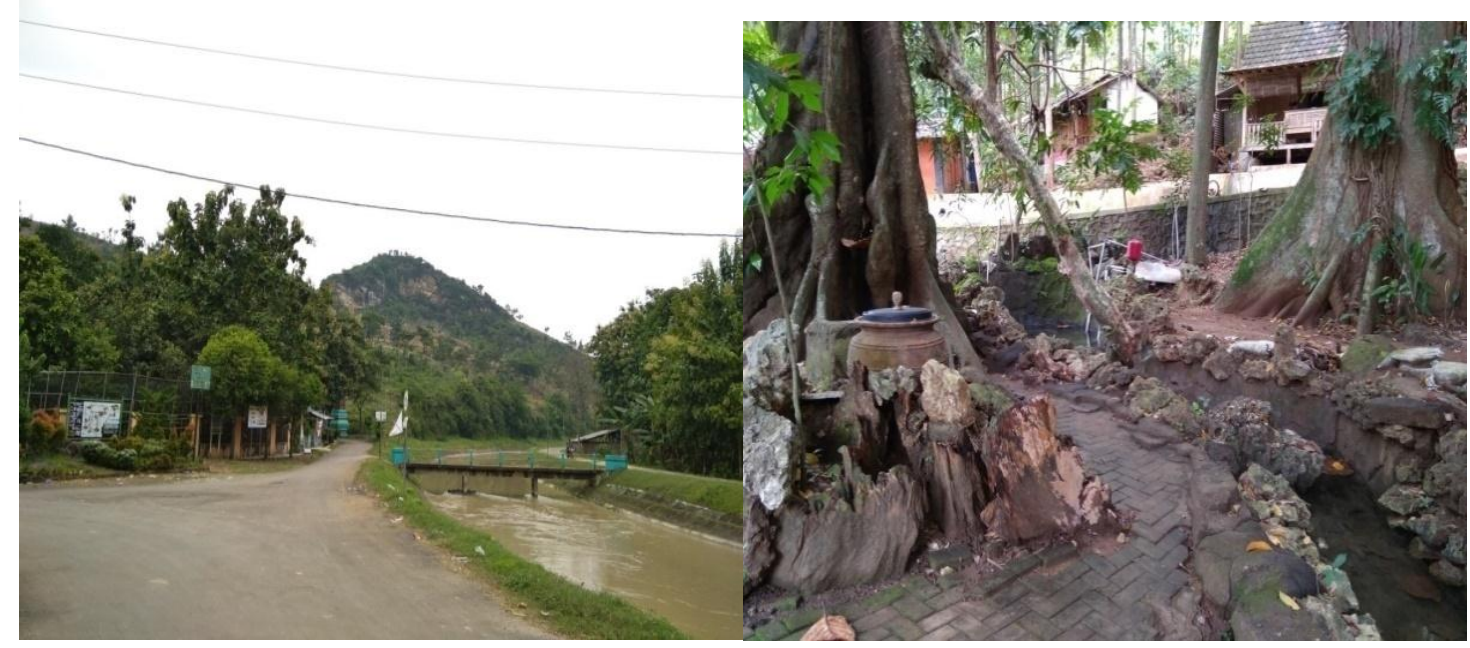

Figure 2. Destinations of Natural Resources in Wonosoco Tourism Village (Source: Research Documentation)

These natural resource destinations reflect priceless natural aesthetic values, because they directly teach the public, especially tourists, about the importance of giving thanks to God Almighty for the gifts that have been given through His creation. The existence of these destinations has also provided education to the community to always protect the environment by not destroying and littering and taking part in caring for and preserving it.

\section{Human Resources Destinations}

The human resources in this village show the uniqueness and have certain characteristics of the local community. This is because the life of this village community is still closely related to the traditions and culture of the village, it can be seen from their life that they still have a high social spirit. They uphold the value of cooperation, harmony, and carry out local customary traditions.

Gotong royong in this village is shown by community participation in sambatan activities, community service, and helping others when there is a celebration or death. Meanwhile, the attitude of harmony that is preserved by the community is by greeting members of the community and helping if some relatives or neighbors in need. Then, the traditions that are preserved are the alms of the earth in the apit month, tayuban in the middle of the rice fields, hajat punden, gablokan, bukak luwur, selametan at the crossroad, slaughtering goats near the sendang. Besides, the economic life of the majority of people as farmers in rice fields can also be used as a destination because tourists can see directly the process of planting rice and at harvest time.

\section{Recreation Facilities}

Recreational facilities in this village are quite complete, namely, there are parks, shops (selling points), sanitation, homestays (shelter houses), and baths (swimming pools). These recreational facilities are made so that tourists feel comfortable in enjoying each existing destination. This shows that there is an attitude of public concern for tourists, resulting in social interaction that results in mutual benefit. This means that the community will get income from the provision of facilities, while tourists will get a satisfaction value from the availability of these facilities.

The existence of recreational facilities directly provides value points for the community about the importance of establishing good socialization by being able to have a 


\section{Tourism Destination Based on Local Values in Wonosoco Village, Kudus Regency, Indonesia Noor Fatmawati, Aditya Isnaini Prasetya}

positive influence on the communities around them. The community will understand the behaviours that should be carried out in interacting with other people. Figure 3 is an example of the condition of recreational facilities in the form of sanitation in the tourist village area.

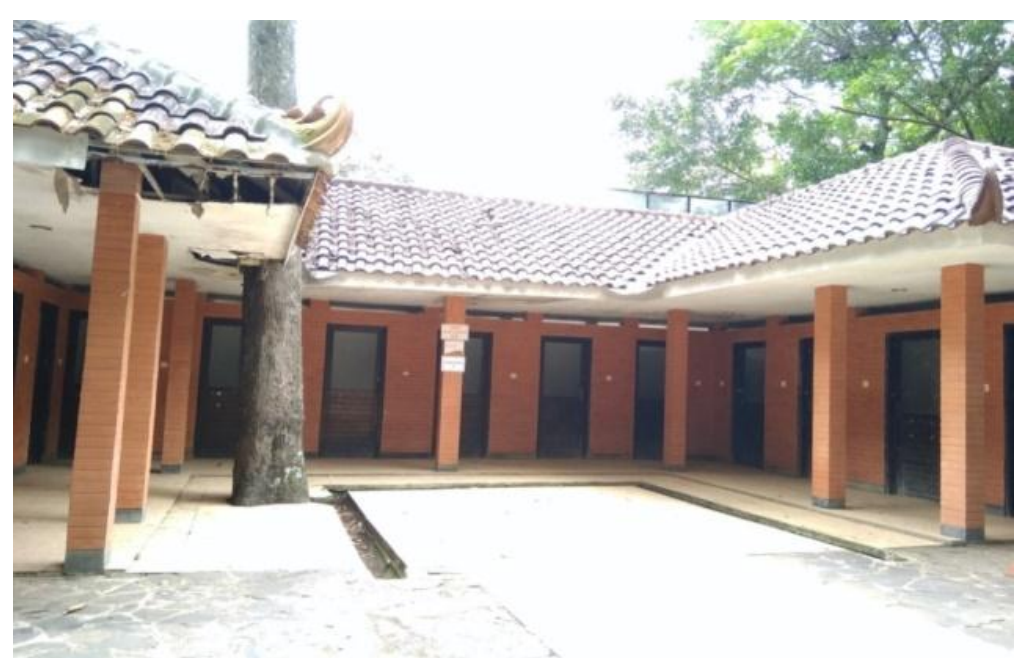

Figure 3. Recreation Facilities

\section{Event}

(Source: Research Documentation, 2018)

Events are activities organized by the village government to attract tourists as well as preserve village culture that contains local wisdom. Events in this village are in the form of a cultural parade, dress-up sendang, and Klithik puppet shows. These events can attract tourists because they are cultural performances that have been preserved from generation to generation by the village community. The event is held consecutively once a year around July or June which coincides with Kliwon Saturday and Legi Sunday.

On Kliwon Saturday, the village government in collaboration with the regional tourism office held a cultural procession that started from morning until midday time. This event provides cultural values that the community needs to understand. The reason is, the cultural parade that shows the production of the land along with the actualization of the traditions and uniqueness of the village is paraded around the village, it has provided understanding to the community, the value of gratitude for the blessings and gifts of God Almighty because their needs have been fulfilled through the harvest. Besides, it is also implied the meaning of togetherness and cooperation which is evidenced by the kinship that the village community maintains in maintaining the integrity of the village and its contents.

On the same day (Kliwon Saturday) and Legi Sunday to be exact ba'da dzuhur, Wayang Klithik performances were held in two sendang (Sendang Dewot and Sendang Gading). Wayang Klitik is a puppet made of wood and tells the story of figures from the kingdom of Java, such as the story of Majapahit. The puppet show implies the value of wisdom that needs to be preserved, where the stories played by a puppeteer named Sutikno to give meaning to the reflection in everyday life. Therefore, in addition to providing insight to the community to preserve culture, this puppet can transfer the educational value that people need to get in carrying out life in the environment.

At the same time as the puppet show, the officials, elders, and the village community did ngebur sendang or rehearsing the sendang. The rehearsals carried out in two springs 


\section{Tourism Destination Based on Local Values in Wonosoco Village, Kudus Regency, Indonesia Noor Fatmawati, Aditya Isnaini Prasetya}

illustrate the community of the need to protect the environment and as evidence of gratitude for the continuously flowing water sources that are used to meet community needs. One form of this event can be seen in Figure 4.

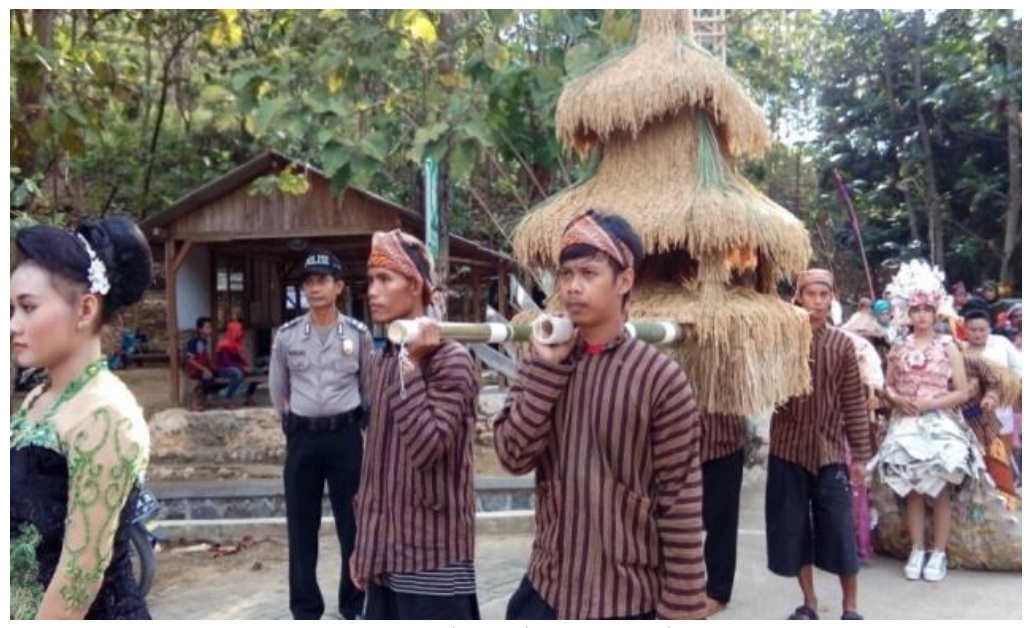

Figure 4. Cultural Carnival Event

(Source: Research Documentation, 2018)

Tourist destinations in Wonosoco Village are very relevant to be used as an education centre because they have local wisdom values that can transfer knowledge to everyone. Susyanti (2014: 68) emphasizes that someone who comes to a tourist village will learn about the environment and local village life, so that there is a learning process from experience seeing the condition of the village. This process Vigotsky in (Sumarsih, 2009: 56) calls it constructivism, where a person forms his or her knowledge through observation in the environment. The knowledge that people get from observing the environment is a cultural process (Vygotsky in Amin, 2012: 122). Bandura reveals the same thing that the cognitive processes in an individual are obtained from the influence of the environment he observes through observation (Laila, 2015: 33).

\section{CONCLUSION}

Tourist destinations in Wonosoco Village, which are destinations for natural resources, human resources, recreational facilities, and events, have the values of local wisdom. These values are spiritual values, social values, and cultural values that can directly construct knowledge for the public and tourists to be realized in everyday life. This tourist destination reflects the local wisdom of the local village that needs to be preserved and preserved to provide a transfer of values to future generations to be able to appreciate the essence of the existing local wisdom values. Therefore, the local government together with the village community need to develop and promote tourist destinations in Wonosoco Village so that they can become a tourist village that provides a multiplier effect for the community.

\section{ACKNOWLEDGMENTS}

The author would like to thank the Head of Wonosoco Village as the main informant who provided an explanation and directed the author in retrieving research data and documents. I would also like to thank the members of the Pokdarwis (Tourism Awareness Group) and the people of Wonosoco Village who have helped me in conducting research. 


\section{Tourism Destination Based on Local Values in Wonosoco Village, Kudus Regency, Indonesia \\ Noor Fatmawati, Aditya Isnaini Prasetya}

\section{REFERENCES}

Amin, A.M. (2012). “Development of Constructivism-Based Biology Learning Tools Based on Vigotsky's Social Theory in High Schools". Jurnal Sainsmat, 1 (2): 109-124.

Fatmawati, N., Setyowati, D. L., \& Utomo, C. B. (2018). "Outdoor Study Activity by Utilizing Wonosoco Tourism Village as A Learning Resource of Social Studies". Journal of Educational Social Studies, 7 (1): 88-98.

Hairumini, Setyowati, D.L., \& Sanjoto, T.B. (2017). “Local Wisdom of Traditional Aceh Houses as Cultural Heritage for Earthquake and Tsunami Disaster Mitigation". Journal of Educational Social Studies, 2 (1): 37-44. ISSN 2502-4442.

Haryanto, J.T. (2013). "Implementation of Cultural, Social, and Environmental Values for Tourism Village Development in Yogyakarta Province". Jurnal Kawistara, 3 (1): 1-11.

Istiawati, N.F. (2016). "Character Education Based on the Values of the Ammatoa Indigenous Local Wisdom in Fostering Conservation Character". Jurnal Cendekia, 10 (1): 1-18.

Laila, Q.N. Albert Bandura Moral Education Thoughts. Jurnal STITNU Al Hikmah Mojokerto, 3 (1): 21-36.

Marpaung \& Bahar. (2002). Introduction to Tourism. Bandung: Alfabeta.

Maryani, E. \& Yani, A. “Sundanese Local Wisdom in Disaster Mitigation and Its Application as a Value-Based Social Science Learning Source". Jurnal Pendidikan Geografi, 114-125.

Moleong, L.J. (2010). Qualitative Research Methodology. Bandung: Remaja Rosda Karya.

Permanasari, I.K. (2011). “Community Empowerment through Tourism Villages in Efforts to Improve Welfare (Candirejo Village, Magelang, Central Java)". Thesis. Jakarta: Universitas Indonesia.

Pitana dan Diarta. (2009). ntroduction to Tourism Science. Yogyakarta: CV. Andi Offset.

Saevi, Tone. (2017). "Phenomenology in Education". Encyclopedia of Educational Philosophy and Theory, hlm. 1790-1795.

Sidik, F. (2015). “Exploring Local Potential to Realize Village Independence”. Jurnal Kebijakan dan Adminstrasi Publik, 19 (2): 115-131.

Susyanti \& Latianingsih, (2014). “Village Potential through Rural Tourism". Jurnal Epigram, 11 (1): 65-70.

Triwardani, R. \& Rochayanti, C. (2014). “Cultural Village Policy Implementation in Efforts to Preserve Local Culture". Jurnal Reformasi, 4 (4): 102-110. 
Tourism Destination Based on Local Values in Wonosoco Village, Kudus Regency, Indonesia

Noor Fatmawati, Aditya Isnaini Prasetya

Wulan, T. dan Khadiyanto. (2013). "Identification of Potentials and Problems of Wonosoco Village in Development Efforts as a Tourism Village in Kudus Regency". Diponegoro Journal of Economics, 2 (2): 1- 